\title{
A voz prosaica e carnavalizada do herói de Hotel Atlântico, de João Gilberto Noll
}

\section{The prosaic and carnavalized voice of the hero in Hotel Atlântico by João Gilberto Noll}

\author{
Diego Gomes do Valle*
}

\begin{abstract}
Resumo: Este trabalho se baseia nas análises do romance de João Gilberto Noll: Hotel Atlântico (2004), colocando ênfase nos aspectos prosaicos e/ou carnavalizantes do romance. Tal análise é norteada pelo apoio teórico de Mikhail Bakhtin, no que tange à voz romanesca (prosaica) e aos temas prosaicos, no sentido lato do termo, ou seja, o prosaico enquanto cosmovisão, em oposição a qualquer concepção idealizante da realidade. Bakhtin contribui basicamente de duas formas para o nosso trabalho: através das teorias sobre o carnaval e sua força destronadora, presentes no livro sobre Rabelais e alguns outros escritos; por meio da teorização da relação do autor-criador e o seu herói, presentes em sua teoria do romance e outros ensaios.

Palavras-chave: João Gilberto Noll. Mikhail Bakhtin. Narrador. Prosaísmo.

Abstract: This article is based on the analyses of the novel by João Gilberto Noll Hotel Atlântico (2004). The article emphasizes the prosaic and/or carnavalesque aspects of the novel. Such analysis is based on the theoretical support of Mikhail Bakhtin in regard to the novelistic voice (prosaic) and the prosaic themes in the broad sense of the term, which is the prosaic as a worldview, in opposition to any ideal conception of reality. Bakhtin's ideas contributed to the analysis with his theories about Carnival and its dethroning power, ideas present in his book about Rabelais and other texts. Another contribution from Bakhtin refers to the theorization about the relation author-creator and his hero, which are ideas present in his theory about novels and other essays.
\end{abstract}

Keywords: João Gilberto Noll. Mikhail Bakhtin. Narrator. Prosaism.

\section{Introdução}

João Gilberto Noll não esconde, em entrevistas, que seus personagens têm uma relação muito similar à do "ator" diante do mundo, como cosmos

\footnotetext{
* Professor Mestre. Doutorando em Teoria e História Literária pela Universidade Estadual de Campinas

- UNICAMP. E-mail: diegouab@gmail.com
} 
ficcional ${ }^{1}$. No romance Harmada (1993), por exemplo, o protagonista é um ex-ator que a todo momento alterna sua realidade com as reminiscências cênicas que seguidas vezes pululam em sua consciência. No caso de Hotel Atlântico (2004), o narrador sem nome se envolve tanto em sua atuação com os outros (usufrui de sua máscara), que a realidade encenada para o outro se converte em realidade possível para si próprio, já que a idealidade/realidade está vazia.

A condição de ator, no contexto em que vivemos, é muito característica, muito factível, já que o sujeito se vê rodeado por uma gama de representações efêmeras, como considera o eminente estudioso Stuart Hall (2003) “(...) somos confrontados por uma multiplicidade desconcertante e cambiante de identidades possíveis, com cada uma poderíamos nos identificar - ao menos temporariamente" (p.13). Deste modo, o modelo do sujeito de Noll pode ser o do ator, com suas múltiplas facetas, que a cada espetáculo atua e acaba logo em seguida para surgirem novas faces.

Assim, o narrador se ilude (nos ilude) que aquele é o seu mundo, e ele (o narrador) consegue atuar satisfatoriamente nele. Até quando ele conseguirá manter esta ilusão é a pergunta que nós leitores podemos fazer.

Desta forma, a relação do narrador com o mundo é sempre conflituosa. Se de um lado temos um acuado "fugitivo" que atua no seu presente com toda sua falta de caráter; do outro, temos os "outros" que não fazem questão de ser coadjuvantes do nosso narrador. Esta relação é importante de se considerar, pois como dizem Clark \& Holquist (2004) " ${ }^{2}$ O mundo em essência não tem significado. As pessoas nada são em essência senão criadores e consumidores de significado" (p.100). Desta forma, sua atuação (criação) não encontra consumidores dispostos a receber, e também a dar forma, a este significado.

Neste mundo tão volátil, líquido em que se locomovem os personagens, não há como delimitar, num plano narrativo, o que se passa na consciência do narrador e o que se passa no espaço delimitado, palpável. São fronteiras tênues que, para nós leitores, dependem muito mais de apostas do que qualquer

\footnotetext{
${ }^{1}$ Em entrevista ao jornal Rascunho (2010), Noll diz: "Hotel Atlântico e Harmada têm como protagonista um ator. Mas ator como sujeito que exercita a dimensão utópica, de fazer exercícios desejantes na medida em que eu possa ser um outro que eu não sou." (p.123).

${ }^{2}$ Katerina Clark e Michael Holquist são estudiosos do filósofo russo, publicaram em 1984 a biografia (v.bibliografia) que sistematiza o conjunto teórico bakhtiniano. Esta obra é de suma importância para os estudos de Bakhtin, pois desvelou tudo que motivou as incompreensões do russo no Ocidente, além de expor minuciosamente os principais conceitos bakhtinianos.
} 
outra coisa, pois este turbilhão de ações que irrompe compulsivamente é a estética do romance em questão, e detectar até onde vai uma fronteira e onde acaba a outra é um primeiro passo à organização do romance. Então, resta-nos refletir e deformar a nossa "realidade" junto com o romance.

É bom que se diga, tal deformação pode não ocorrer no leitor, pois dependerá de seu repertório. Sem dúvida, a atitude é possível, e cause um efeito mais agudo em tal leitor, uma vez que Noll agride as convenções literárias constantemente e o leitor pode vivenciar tal efeito em sua total potência estética, diferentemente de um leitor "convencional".

Há uma descentralização na atitude do leitor, ele se torna muito ativo e, dentro de seu pacto ficcional, poderá estar desprovido de qualquer "decência", no plano estético-ideológico. Do contrário, o leitor "decente" considerará a obra de Noll um mero estilo depravado, ou algo do gênero. O que não deixa de ser um efeito possível e legítimo, pois seria coerente com a atitude de um determinado leitor.

Este leitor também poderá ter uma atitude exotópica de sua parte. $\mathrm{Ou}$ seja, este pode se colocar em uma posição diferente da que ocupa no plano do real, ao invés de contemplar o mundo ficcional somente como obra de arte, no plano estético, com o pacto ficcional (que é um pressuposto da contemplação estética); ele poderá distorcer, mesmo que temporariamente, seu plano ético-ideológico. Sem tais valores éticos, a estética de Noll atinge um significado sui generis, já que nega a maioria dos valores éticos ocidentais presentes no "real".

Se pensarmos em termos do "leitor-modelo" de Eco (1994) este leitor é o sujeito "que está ansioso para jogar" (p.16), ele apreende as regras do jogo e está disposto a segui-las. Sendo assim, consideramos que o leitor empírico tem a possibilidade de sobrepor suas expectativas (e isso é legítimo) e não ser o leitor-modelo. Ambos os efeitos jogam com valores éticos e ideológicos, assimilando-os ou refutando-os.

É importante sublinhar, retornando ao plano estrutural do romance, que o fato de os espaços onde se desenvolvem as principais ações deste romance serem hotéis ou localidades alheias e temporárias é um indicativo que reforça a fugacidade e hibridismo das identidades presentes. Os sujeitos acabam pertencendo, ao mesmo tempo, a muitos lugares - e assim a nenhum lugar em particular. 
Desta forma, buscaremos mostrar que o protagonista de Noll utiliza a máscara (motivo carnavalesco clássico utilizado de forma conveniente ao nosso tempo) para possibilitar o encontro com diversos "outros" em situações que permitam um fluxo de identidades, a relativização da verdade, como atesta Bakhtin (1997): "A máscara traduz a alegria das alternâncias e das reencarnações, a alegre relatividade, a alegre negação da identidade e do sentido único" (p.35).

Este recurso da máscara é mais um entre os muitos que demonstram como Noll sugere um retorno à praça pública, onde se origina o romance. $\mathrm{O}$ prosaísmo presente em sua obra busca sempre um "olhar para baixo", uma descentralização dos motivos ditos "nobres". Há verdadeiramente uma implosão dos motivos clássicos e até das técnicas narrativas que consagram o tempo e o espaço como fundamentais para se "contar algo". Neste mundo prosaico, a abertura para o mundo é fundamental, a sexualidade se torna algo muito mais volátil que o "corpo burguês": fascinado pela fuga social.

A praça pública é onde o corpo grotesco se movimentava em total liberdade. Ali, o sujeito não possuía hierarquias e medos, somente a realização do corpo em sua integridade. As regras de decência são temporariamente abolidas. Até o vocabulário utilizado entre os sujeitos é de total liberdade:

Os elementos da linguagem popular, tais como os juramentos, as grosserias, perfeitamente legalizadas na praça pública, infiltravam-se facilmente em todos os gêneros festivos que gravitavam em torno dela (até no drama religioso). (BAKHTIN, 1999, p.132).

Quem se encontrava na praça pública estava misturado à massa, não havia a delimitação burguesa do que pertence a um ou a outro. A quebra de hierarquias e a familiaridade imperavam:

A praça pública no fim da Idade Média e no Renascimento formava um mundo único e coeso onde todas as "tomadas de palavra" (desde as interpelações em altos brados até os espetáculos organizados) possuíam alguma coisa em comum, pois estavam impregnadas do mesmo ambiente de liberdade, franqueza e familiaridade. (BAKHTIN, 1999, p.132).

Por isso, argumentamos que os personagens de Noll estariam muito coerentes no ambiente da praça pública. Uma característica marcante nos heróis de Noll, e que eram marcantes na praça pública descrita por Bakhtin, é que eles urinam e defecam. Tal característica de tão trivial se torna inusitada, 
devido a que poucos personagens da literatura agem com tanta naturalidade diante de nossos olhos. Bakhtin reflete sobre tais dramas corporais da seguinte maneira: "Pode-se afirmar que a satisfação das necessidades é a matéria que melhor se presta à encarnação degradante de tudo que é sublime" (BAKHTIN, 1999, p.130).

Sendo assim, é momento de analisarmos este sujeito que poderia se encontrar na praça pública, no entanto se vê obrigado a viver obstinadamente em locais que não preenchem suas pulsões. Comecemos com o primeiro ato de Hotel Atlântico.

\section{Primeiro ato $^{3}$}

A narrativa se inicia com ações que irrompem de todos os lados, ativando os principais sentidos: choro e uma avalanche de pessoas. Um corpo sendo levado por policiais e uma mulher de cabelo pintado, com tique nervoso. Uma cena no mínimo inusitada para se iniciar um romance, mas que serve para o nosso narrador subir ao palco e começar a sua encenação que se chama Hotel Atlântico.

A primeira impressão que temos deste narrador é que ele se sente um acovardado: "Mas recuar me pareceu uma covardia a mais" (NOLL, 2004, p.9). Estas covardias são uma marca característica dos narradores de Noll, influência de Kafka que foi admitida pelo autor em diversas oportunidades. Como todo sujeito que se sente acovardado, ele é um fugitivo em potencial, um perseguido, um "sujeito em trânsito".

Em termos bakhtinianos, consideramos a presença de Kafka em Noll como um exemplo de dialogismo. Este dialogismo da palavra literária é um tema discorrido principalmente no livro Questões de literatura e estética (1998). E podemos sintetizá-lo, tendo em vista nosso objeto de estudo, como imagens kafkianas reacentuadas pelo romancista gaúcho. Tal reacentuação servirá para atingir novos efeitos estéticos no romance, aliás, essa característica é fundamental para a sobrevivência e renovação do antigênero romanesco.

\footnotetext{
${ }^{3}$ Chamaremos de Atos às partes de nosso artigo, pois há entre estas partes um breve espaço de uma página no romance, fato incomum nos romances de Noll.
} 
Retornando à trama, a perseguição no romance é percebida pela voz do herói, à qual temos acesso diretamente em sua consciência. Tal sentimento imputado ao outro é causador de um discurso acovardado do herói, fato que condiciona o diálogo no limiar, tendo em vista que uma situação de crise está sempre a ponto de acontecer (pela ótica do narrador, que é quem concebe a perseguição no outro).

Este narrador/ator/protagonista se utiliza dos atritos externos ou de sua consciência para atuar de maneiras diversas durante a narrativa. O primeiro embuste deste ator é o fato de ele ser o portador da voz narrativa. Este embuste dá a ele o direito de, se quiser, criar fatos, supor reações nos outros, enfim, mentir sem o menor pudor a todos os que o ouvem.

Deste fato podemos fazer alguns apontamentos: a voz do narrador, como de um típico narrador do romance, aos moldes de Bakhtin, não é totalizante, única, dogmática; pelo contrário, ela é a voz que devemos conservar sob um olhar enviesado, pois ela não faz questão nenhuma de trazer o leitor para o seu lado. Outro apontamento inicial é que esta atuação do narrador é relativizadora da realidade, pois o leitor, como ouvinte privilegiado da consciência do ator, pode perceber, a partir de uma hipótese ou de uma mentira que sai espontaneamente, a construção de uma realidade "paralela" que tem tanta ou mais importância que a narrativa externa à consciência do herói. Desta maneira, o romance vai se fazendo de amontoados de desautorizações da voz narrativa, ao ponto de o leitor se sentir o único responsável por organizar estas vozes fragmentadas e fragmentárias. Neste panorama de indefinição e caos, o leitor, com seu excedente de visão, pode ser o "sujeito" que organiza e preenche as lacunas deixadas.

Esta sua atuação soa ridiculamente quando se depara com as reações insignificantes dos outros personagens. Em algumas linhas, ele atua duas vezes sem obter grandes reações: primeiramente uma "gargalhada despropositada", que é simplesmente ignorada pela moça do balcão; depois, "como deveria estar num dia para canastrão" (NOLL, 2004, p.10) ele tem uma atitude cavalheiresca ao beijar a mão da moça e novamente é ignorado. As falas da moça são providenciais para que tenhamos um reflexo do narrador: a todo momento a moça se mostra extremamente centrada em atender um "cliente" como qualquer outro, ou seja, não demonstra um afeto especial, diferenciado ao narrador. As únicas afetividades que existem ficam por conta do nosso narrador e sua conduta pouco confiável: "Ela disse com um olhar já completamente 
embevecido (...) Ela informou com uma delicadeza que me fez sentir cócegas na nuca" (NOLL, 2004, p.10). Desta forma, percebemos uma dissonância grande entre as réplicas da moça e as percepções do narrador, como se ele quisesse se convencer e convencer o leitor de algo que de fato não está ocorrendo. Nada que não esteja nas funções do ator.

Refletindo sobre a problemática da voz que é desautorizada constantemente, conceituando-a dentro do gênero romanesco, enfatizamos que esta é uma característica do romance e, antes, uma condição da palavra prosaica. Tal palavra deve ser desautorizada, pois ela vive dessa constante mobilidade, se sua voz fosse unívoca, autoritária, perderia uma de suas características estético-ideológicas principais.

Assim, temos este embate inicial entre o ator sem palco e o público que não "ouve" o ator. Diante deste quadro, o narrador não hesita em construir uma realidade paralela (mentirosa) que tem tanto poder quanto a realidade concreta:

Preenchi a ficha do hotel, estado civil casado eu menti - e imaginei uma mulher me esperando num ponto qualquer do Brasil, e divaguei que ter esta mulher me esperando poderia atiçar a curiosidade da moça da portaria sobre mim. (NOLL, 2004, p.10).

Não podemos desconsiderar também a presença determinante do outro em suas ações, a ação ativa que o outro tem em seu discurso, já que a moça participa presencialmente na elaboração discursiva do narrador.

O narrador, em seu afã de ator, não consegue sofrer a ação externa passivamente, ele tenta ser o "senhor" da ação, dominar o palco. Prova disso é que ao ouvir alguns gemidos de algum quarto ao lado, ele se sente acuado, "muito nervoso" e, depois, "levemente excitado". De chofre, ele retoma a ação para si e conduz os movimentos até o ato sexual com a moça da recepção. Sexo este que ele faz questão de dizer que é casual: "Nenhum toque acima da cintura, nada que não fossem ancas anônimas se procurando, patéticas." (NOLL, 2004, p.12). Eis um exemplo de prosaísmo, o retorno à praça pública ${ }^{4}$, onde $\mathrm{a}$

\footnotetext{
${ }^{4}$ É bom que expliquemos, a tempo, essa metáfora da praça pública não se refere ao espaço físico (já que o narrador está em um quarto) ela é aplicada com o sentido que Bakhtin dá, em particular no segundo capítulo de seu livro sobre Rabelais: $O$ vocabulário da praça pública na obra de Rabelais (1999, p.125). Tal praça pública remete a uma atmosfera de ausência de qualquer tipo de hierarquia, de total intimidade e liberdade.
} 
moça se torna um mero objeto de gozo, desprovida de qualquer idealização e também de qualquer sentido de congraçamento, de encontro efetivo e humano com o outro, sendo a moça objetificada, apenas desaguadouro das pulsões do narrador. Desta forma, as ações iniciais do romance se encerram com o nosso ator em pleno domínio da cena, dono da narração com sua voz mal remendada.

A este conflito entre o ator e o mundo, descrito anteriormente, adiciona-se neste momento uma "necessidade de ir" que a todo momento o narrador se cobra: "Pensava na minha ida, até quando eu aguentaria" (NOLL, 2004, p.13). Ao leitor esta "necessidade" produz muitas possibilidades, pois houve um crime neste hotel, há mancha de sangue no carpete, pode ser o sangue do crime, assim como pode estar relacionado com a cópula que aconteceu neste carpete. Seria o narrador o criminoso? Aparentemente não, a sua culpa é muito mais um sentimento, algo que ele imputa ao outro e que é, como vimos no início, anterior ao crime.

O antigo conflito com o mundo retorna neste ínterim: a ação externa que se apossa momentaneamente do foco narrativo. Pelo olhar de um garoto uma pomba e seu filhote são vistos no ninho. Esta cena poderia, em um romance "dos ditos decentes dos tempos modernos" (BAKHTIN, 1997, p.279), por exemplo, render longas descrições, filosofias sobre o amor maternal inspiradas no trato da ave com seu filhote, enfim, divagações que o narrador faz questão de ignorar ao fechar a janela bruscamente e retomando seus conflitos.

Começa então a refletir sobre a sua ida. Este é o primeiro momento em que ele explicita a sua atuação diante do mundo: “(...) Daqui a pouco eu precisava ir - aparentando calma, muita calma. Se eu encenasse loucura, quem sabe um transido esquecimento de tudo, o mundo correria para me internar" (NOLL, 2004, p.13). Neste momento surge uma indagação que é muito própria do ator:

E não seria a mesma coisa que viajar? Com a vantagem de eu não depender de qualquer esforço, como o de entrar e sair de espeluncas como aquela em que eu estava. Se eu ficasse louco eu permaneceria dopado dia e noite, dormindo à hora em que a minha cabeça caísse de torpor. (NOLL, 2004, p.13).

Desta maneira, fica claro que a mudança de espaço, e até a própria configuração do cronotopo, se opera a partir da consciência e de sua expressão 
pela linguagem. A viagem acontece em decorrência da atuação e suas consequências nos outros.

Logo em seguida, o narrador dá um exemplo de como a consciência, a partir daquela mesma mancha no tapete, desenvolve a hipótese de, sim, aquilo ser o sangue do crime e quem atirou foi ele mesmo. Esta hipótese é desdobrada até as últimas consequências:

Um tiro, por que não? Sim, também eu mataria, e ganharia uma cela e comida do Estado. Talvez voltasse ao desenho que eu abandonara na adolescência. Ficaria desenhando o dia inteiro se os outros presos deixassem. À noite cairia de sono. Para na manhã seguinte despertar e dar continuidade à linha interrompida no dia anterior. (NOLL, 2004, p.14).

Não deixa de ser um exercício extremo de alteridade, a ele não tão penoso, já que o "sentir-se criminoso" não é tão alheio ao seu sentimento de fugitivo. Neste movimento contínuo da consciência de nosso ator, a memória é ativada e com ela as reminiscências que Eva (relacionamento casual) dizia a respeito do ócio dele: “- O que te falta é ocupação regular" (Idem). Esta frase é um exemplo claro de como a voz do outro é terrivelmente imperiosa em nossa maneira de enxergar a nós mesmos, como salienta Bakhtin:

As relações dialógicas são possíveis não apenas entre enunciações integrais (relativamente), mas o enfoque dialógico é possível a qualquer parte significante do enunciado, inclusive a uma palavra isolada, caso esta não seja interpretada como palavra impessoal da língua, mas como signo da posição semântica do outro, ou seja, se ouvimos nela a voz do outro. (1997, p.184).

Afinal, como não se afetar por aquilo que é dito a nós diretamente, se, como vimos, até o que não é dito é levado em consideração? $\mathrm{O}$ ator demonstra sua indignação diante desta suscetibilidade, por mais que tenha sido eufemística a sentença, diante do discurso do outro: “- Um desocupado, é disto que te chamam - eu costumava dizer sozinho diante do espelho" (NOLL, 2004, p.14). E desta maneira, o narrador desperta de seu delírio, gritando o que os outros dizem sobre ele.

Posteriormente, ele liga para a recepção, onde novamente nota-se algo de artificial nos comentários sobre as réplicas da moça. Um exemplo disto é que a moça pergunta o nome dele, ele responde "Amor, me chame de Amor, Verbo Encarnado" (Idem). Aí se explica, em parte, o título provisório que 
este romance teve: "O homem que queria ser Deus" 5 , aliás, o nome do filme, de que nosso ator teria participado (informação dada no terceiro ato). Sem muitos diálogos, eles chegam ao ato sexual. $\mathrm{O}$ ator já estava novamente no palco, palco erigido nos moldes prosaicos da realidade: sátira do amor ágape cristão, e o gozo destronando o romantismo idealizante.

Logo em seguida, ele tem outro contato com o espelho. Este encontro nos romances de Noll é uma constante presença. Tal reflexo em especial é uma mostra de como o espelho exibe como o ator é, ou seja, como os outros o veem e moldam a sua concepção sobre si.

Nota-se então esta constatação da influência do outro que está comigo diante do espelho. Este encontro produz no narrador, logo depois, um "olhar envelhecido" notado pela moça da recepção. Antes de sair do hotel, o ator age de forma nitidamente piegas, romântica, o que proporciona uma cena patética, tanto que ele próprio se sente "ridículo" por ter que interpretar este papel naquele momento: "Falei que um dia a gente ia se rever, me sentindo completamente ridículo" (NOLL, 2004, p.17). Ou seja, o discurso amoroso, convencionalmente construído, é aceito momentaneamente pelo narrador para atingir o seu fim, mas interiormente este mesmo discurso é refutado na sua integridade.

Já havíamos chamado a atenção que o narrador de Noll se presta externamente a determinados discursos para refutá-los dialogicamente, e não de forma niilista, que resultaria em mera negação unívoca. O herói aproveita a representação que não lhe convence internamente e lhe impõe uma estética nova, ao avesso.

Assim termina este primeiro ato, com o ator se despedindo do seu primeiro abrigo. Os capítulos que se seguem vão acumular muitos dos recursos estilísticos citados anteriormente, por isto levaremos em consideração os recursos inéditos e que fomentem novas discussões para a análise. Da mesma forma, buscaremos não nos repetir nas problematizações bakhtinianas.

\footnotetext{
${ }^{5}$ Em O mito de Sísifo, diz Camus (2005), sobre Kirilov, herói dostoievskiano de Os demônios: "Tornar-se Deus é apenas ser livre nesta Terra, não servir a um ser mortal. É sobretudo, naturalmente, extrair todas as consequências desta dolorosa independência. Se Deus existe, tudo depende dele e nada podemos fazer contra sua vontade. Se não existe, tudo depende de nós. Para Kirilov, assim como para Nietzsche, matar Deus é tornar-se deus (p.122).
} 


\section{Segundo ato}

Neste momento, o nosso ator enfrentará o mundo e sua rotina alucinante. Ele não terá mais o seu hotel como local seguro de encenação. Agora seu espaço será dividido entre um turbilhão de pessoas desconhecidas e que o oprimem consideravelmente.

No momento em que ele sai do hotel já fica hesitante, pensa em desistir de sua saída. Percebe-se que com o espaço aberto, o mundo em sua amplitude deixa-o com a mente aturdida, sua consciência fica caótica ao extremo. Sua saída é encontrar um táxi, local fechado, que lhe devolve momentaneamente alguma lucidez. Com a consciência em ordem, o ator pode atuar com desenvoltura, já no táxi ele assume o papel de alcoólatra. Na rodoviária, quando sai do táxi, se depara com o mundo novamente e, de novo, se sente mais acuado ainda, reflete que o mundo e seu ritmo alucinado não são o melhor palco, ali ele é anônimo, não há controle algum sobre aqueles outros, a não ser sobre o seu boné, exigindo deste objeto somente sua submissão.

Resolve comprar uma passagem para Florianópolis, uma ilha, descolada do continente, que guarda alguma similitude com sua condição de despegado daquilo que o originou: a sociedade; semelhanças simbólicas que vão se acumulando.

Dentro do ônibus, (cronotopo que proporciona o encontro de pessoas totalmente diferentes) ele conhece uma ruiva, Susan e, incrivelmente, se instala um diálogo espontâneo, com réplicas bem desenvolvidas e sem os corriqueiros comentários superficiais do narrador, que revelam sua destoante atuação.

Esta inusitada fluidez no diálogo se explica posteriormente, quando o narrador, ao ver uma notícia de jornal em um prostíbulo, constata que Susan mentiu em grande parte da conversa, ou seja, durante a viagem, a ruiva domina a atuação e conduz o diálogo verborragicamente. Ela está, assim como nosso herói, fugindo de sua realidade. Daí se explica o colóquio bem encaminhado pelas partes: são dois atores que perambulam em plena ação.

A conversa é tão "natural" e acompanhada de carícias, que chega a fomentar no leitor uma expectativa de algum enlace afetivo entre os dois. No entanto, a ruiva é encontrada, depois do sono, em estado deplorável: "Então me virei para o lado, e vi que Susan tinha uma substância com jeito de pastosa mas já ressequida na beirada da boca, no queixo, manchando o suéter preto (...) A boca estava aberta, a língua à mostra" (NOLL, 2004, p.30). Esta imagem 
é de requinte grotesco e afasta qualquer possibilidade de idealização sobre a mulher, novamente a atmosfera prosaica é retomada. A imagem é grotesca, pois liga a mulher ao eterno movimento da vida. No entanto, para retratar o movimento grotesco, é necessário desvelar o ser de sua decência, de sua beleza, já que tais atributos servem somente como superficialidades, convenções que não servem para retratar os personagens de Noll.

Ele constata que ela houvera se suicidado com medicamentos. Fato este que, a alguém que já se sente perseguido, causa um pânico dobrado, pois ela estava ao seu lado e se manteve tão íntima e uma espécie de sentimento de culpa surge neste momento no ator. Ele vê, em cada pessoa que cruza com ele, um olhar inquisidor, uma intimidação constante. Quando ocorre a morte de Susan as máscaras caem e se vislumbra a representação mimética/estética da punição do "real".

Consegue se desfazer desta impressão, depois, ao entrar em uma livraria e se entreter com uma história lida esparsamente, ou seja, liga-se a outras linguagens.

\section{Terceiro ato}

Já em Florianópolis, ele decide buscar um refúgio, no hotel, ao som de Francisco Alves. Esboça algum sentimentalismo, chega a lembrar da moça da recepção, no entanto volta atrás: "Mas súbito me veio um inconformismo, mordi a mão, o braço, e comecei a gemer e a rolar pela cama até cair num tapete peludo. - Morri, me enterrem! - exclamei” (NOLL, 2004, p.37). Desta forma, ele se afasta de qualquer tipo de ligação que transcenda o seu mundo prosaico e sua atuação com os outros, nada pode atingir o que há por debaixo da sua máscara.

Decide viajar com dois desconhecidos ao Rio Grande do Sul e depois ao oeste de Santa Catarina. Um deles (Léo) se casará e o outro (Nélson) é irmão adotivo da noiva. O irmão promove uma despedida de solteiro ao cunhado durante a viagem. Toda a festa, o ritual que envolve aquele que irá se casar, as falas, enfim, aquela cena parecia ao narrador "um filme antigo", e ele os contempla e deixa-os atuar sem participar da orgia, cede o palco a eles. A relação entre Léo e Nelson é uma relação conflituosa, tal como se configura uma relação, convencionalmente, entre pai e filho. Encontramos outros exemplos 
deste vínculo retratados em outros textos desde Caim e Abel da Bíblia a Esaú e Jacó de Machado de Assis.

Bakhtin fornece uma importante reflexão sobre a festa carnavalesca, que podemos deslocar para a orgia que ocorre neste momento do romance, afinal o bordel ainda é o local onde ocorrem as festas não-oficiais:

Ao contrário da festa oficial, o carnaval era o triunfo de uma espécie de liberação temporária da verdade dominante e do regime vigente, da abolição provisória de todas as relações hierárquicas, privilégio, regras e tabus. $(1999$, p.8).

Nélson é quem promove a orgia para Léo, o pai apresentando o mundo erótico ao filho. Nélson é sempre opressivo com Léo, há sempre um tom dominador na voz de Nélson ao se dirigir a Léo. Ou seja, um vínculo opressor e de notada superioridade de um sobre o outro: a noiva de Léo foi desvirginada por Nélson e se pensarmos nesta figura paterna, compreendemos melhor a simbologia que é expressa por Nélson:

(...) A minha querida irmãzinha, ela sim, eu fui o primeiro a comer minha maninha quando ela tinha doze anos! Nélson puxou a cabeça de Léo pelos cabelos, e fez Léo beijar a sua braguilha: - Beija, beija aqui o cara que abriu o caminho pra você seu puto, beija! (NOLL, 2004, p.54).

O narrador se refugia em um quarto. Neste quarto, há uma inversão aguda de representações. As descrições do quarto, o modo como é acolhedor, torna o lugar com aspecto de "lar", sem uma atmosfera erótica, inclusive com um Cristo Crucificado na parede. Estes traços se acentuam quando uma das prostitutas entra em seu quarto e o trata com uma afetividade tocante, inclusive ao dessacralizar a imagem paterna, pois ela empresta o pijama, que fora do pai dela, a ele, um cliente em potencial. Podemos dizer que se "carnavalizam" o ambiente e as relações envolvidas nesta cena, considerando que se invertem, de forma ambivalente, os dois polos bem estabelecidos na sociedade: "prostíbulo é sinônimo de sexo sem afeto"; "pai é único, e o seu amor é intransferível". Um duplo destronamento em prol de uma atmosfera prosaica.

Para a reflexão sobre essa importante passagem do romance, citamos Bakhtin em Cultura Popular na Idade Média e no Renascimento: o contexto de François Rabelais (1999), que diz sobre o riso carnavalesco: 
$\mathrm{O}$ verdadeiro riso, ambivalente e universal, não recusa o sério, ele purifica-o e completa-o. Purifica-o do dogmatismo, do caráter unilateral, da esclerose, do fanatismo e do espírito categórico, dos elementos de medo ou intimidação, do didatismo, da ingenuidade e das ilusões, de uma nefasta fixação sobre um plano único, do esgotamento estúpido (p.105).

A citação elucida a carnavalização presente em todas as relações envolvidas: na do cliente com a prostituta, na religião (representada por Cristo crucificado), na figura paterna trazida para uma relação de iguais. Ou seja, em um único momento do romance se conseguiu novas possibilidades de representação para figuras, comumente estereotipadas (seja de uma forma autoritária, no caso da religião, seja de forma negativa, é o caso do bordel e a prostituta).

Tais figuras cristalizadas são postas de forma invertida, ao avesso, justamente para denunciar sua superficialidade e, num plano estético-ideológico, Noll coloca em cheque a validade de se representar tais elementos em sua uma possibilidade única, sem conceber o avesso destes elementos com igual legitimidade.

Posteriormente, eles chegam à Fazenda Oásis. Os dois entram e o narrador vai até um rio próximo, onde ele encontra mancha de sangue na areia. Logo percebe que Nélson e Léo temiam que o ator soubesse de um crime (que não é desvendado pelo herói nem por nós leitores), e que deveria ser morto. Subitamente, ele foge pela mata e, entre tiros, consegue sair ileso. É a primeira vez que ele fora perseguido verdadeiramente. Agora é hora de recomeçar.

\section{Quarto ato}

Se ele havia chegado até ali ao acaso, de maneira igual ele sobe em uma carroça e segue para Viçoso, onde é acolhido em uma igreja. Há um dia ele estava em um prostíbulo, onde havia um crucifixo, agora acontece o mesmo na igreja. Devemos ver esta estada na igreja, acolhendo um sujeito, desprovido de qualquer credo, como uma ocasião cronotópica de se tornar possível e justificar o jogo livre com as linguagens sagradas, carnavalizar os dogmas com o direito exterior (tempo/espaço) e interior (consciência).

A possibilidade deste sujeito, que até então se demonstrou erotizado, zombador, sem grandes afetos, estar em um ambiente avesso a todos esses 
atributos, proporciona o fundo perfeito para ele carnavalizar todos os elementos unívocos que surgirem.

Bakhtin define assim esta carnavalização: "O traço marcante do realismo grotesco é o rebaixamento, isto é, a transferência ao plano material e corporal, o da terra e do corpo na sua indissolúvel unidade, de tudo que é elevado, espiritual, ideal e abstrato" (1999, p.17). Este rebaixamento será notado em diversas ocasiões neste capítulo.

Ao despertar, no dia seguinte, ele toma banho e veste, pela falta de roupa, a batina de um padre falecido. Eis a primeira de uma série de iconoclastias presentes neste episódio.

Antônio, o homem que cuida da igreja na ausência do padre, conta que quando viveu em Roma, berço da Igreja Católica, foi mendigo e acolhido por um albergue de freiras, onde atacou à força uma delas. Posteriormente não precisou mais de força, pelo contrário, os encontros serviam de moeda de troca para o alimento. Antônio deixa claro que "nem sempre estava com disposição", mas tinha que realizar sua "missão", ou seja, saciar o apetite sexual da freira que era superior ao dele. Relação similar se estabelecia na carnavalização da Idade Média, quando se aproximava o baixo material corporal (lascívia) à verdade oficial (clero), neste caso com os padres.

Sobre esta tradição de se ligar a figura eclesiástica ao sexo, figura cuja fertilidade é sempre uma característica, Bakhtin (1999) cita como Rabelais explora o tema:

As frases de Frei Jean afirmando que 'só a sombra do campanário de uma abadia já é fecunda' e que o hábito monacal pode restituir a um cão a sua virilidade perdida, e o projeto de Panurge de construir a muralha de Paris com órgãos genitais. (p.266).

A tradição em se assimilar a função sexual potente, fértil ao sacerdote se deve pela incompatibilidade do sexo com o discurso religioso. $\mathrm{O}$ sexo torna o sujeito mais humano, afastando-o de Deus. A partir do momento em que um padre ou uma freira são retratados como lascivos, eles se convertem em mais humanos, mais longe do céu e mais perto da terra. Também há a constatação de que o corpo não deixa de se movimentar nunca, mesmo sob rígidos códigos morais. 
Durante esta narração de Antônio, o nosso ator demonstra fidelidade a sua atuação clerical ao assumir que a batina funciona como um vínculo entre ele e a conduta cristã sacerdotal:

Aquela história começava a me deixar nervoso. Afinal eu estava de batina, aquilo tudo me dizia respeito (...) Ouvir, dentro de uma batina, a história da freira voraz me deixava num incômodo que eu esperava desmanchar caminhando lá fora. (NOLL, 2004, p.64).

Ao sair para caminhar, ele realiza outra cena tipicamente carnavalesca. Com a batina à altura da canela e com uma lasca de madeira (cajado) ele percorre a rua, com pessoas pedindo benção e se ajoelhando diante dele. Importante notar que, como temos acesso a sua consciência, não há neste momento uma intenção zombeteira, blasfema nos seus atos, há, sim, certa naturalidade. Assim, esta carnavalização se dá por uma inferência inevitável do leitor, já que no ator não há ação satírica clara, levando-se em consideração que temos acesso a sua consciência e sabemos de todas suas intenções.

Há tanta naturalidade em suas atitudes que o "padre" entra, sem ser requisitado, em uma casa onde agoniza uma senhora. Naquele momento, o ator/ padre pratica a extrema-unção, um dos sete sacramentos da Igreja. Percebemos então até que ponto a atuação se enraizou, naquele momento, em nosso ator. A ele não interessou que não tinha autoridade adquirida para exercer a função de padre, o que lhe importou é que os outros acreditaram que ele podia fazê-lo, e isto basta. O mundo ficcional, novamente, em pé de igualdade com o real, e a coroação/destronamento da função do padre.

Também presenciamos a desmistificação da morte e o desvelamento das falsas seriedades instituídas pelos homens. Tais concepções estão presentes no modo como o grotesco se manifesta enquanto estética, como fica claro nesta citação de Bakhtin:

A vitória sobre a morte não é absolutamente a sua eliminação abstrata, é ao mesmo tempo o seu destronamento, sua renovação, sua transformação em alegria: "o inferno" explodiu e converteu-se numa cornucópia (...) Todas as coisas terríveis, não-terrestres, converteram-se em terra, isto é, em mãe nutriz que devora para de novo procriar outra coisa, que será maior e melhor. (1999, p.79).

Ao voltar à igreja, o ator decide abandonar o "sacerdócio" e mergulha na cena de um padre em plena ação sexual com a mulher que faz os serviços 
domésticos da igreja. A mesma lascívia atribuída aos clérigos anteriormente, então, reaparece. Eis o mundo da praça pública, onde as relações hierárquicas não existem mais, o gozo é a ordem.

Ao ir embora da igreja, o narrador, na rua, cruza com um garoto. A cena que os dois proporcionam destoa de todo romance até então:

(...) a criança num momento me notou, e ela estava sorrindo, não sei se estava feliz por algum motivo, o que sei é que ela sorria, e quando me viu não desfez o sorriso, aquele sorriso me incluía também, e eu também sorri. (NOLL, 2004, p.71).

Depois de carnavalizações e atuações com muita espontaneidade durante o capítulo, o ator é sincero e recebe um sorriso sincero de uma criança. Uma fagulha de utopia em um caótico mundo.

A imagem desta criança aparece com muito contraste, em relação à atitude corriqueira do narrador. A criança não ocasiona ao narrador nem a atitude desmerecedora, nem algum tipo de deboche, natural em sua relação com o outro. Aqui se destaca justamente por destoar da sua condição comum, o narrador vê no outro algo que não costuma encontrar e em decorrência de uma simples e inesperada atitude do garoto.

\section{Quinto ato}

Agora, depois de enfrentar uma chuva torrencial e estar enlameado, ele chega à outra cidade próxima (Arraiol). É recebido com hostilidade pela dona de uma casa em que ele bate. Inclusive é confundido com um sequestrador. Em seguida, em outra casa, o dono (homem careca e gordo) aponta uma arma em sua direção e com desdém o nosso herói dá as costas. Desmaia, talvez com um tiro do careca, ou dos policiais que se aproximavam. Não há clareza do discurso romanesco para a cena, porque tudo está esfumado num clima nonsense.

Ele acorda no hospital, com o careca gordo ao lado. Agora se sabe que ele é o cirurgião da cidade e candidato a prefeito. Ele havia amputado a perna de nosso ator. Dentro da moldura da situação, notamos outra similaridade com Kafka: o sujeito que é punido, sem saber a razão exata, e, o mais impressionante, não procura saber, ignora ou se atém a outros fatos que não a 
razão de seu castigo. Há um desconhecimento consciente, um contorno daquilo que está diante de seus olhos.

Sua reação inicial é de que se trata de um pesadelo, depois, de que as pessoas estão representando algo em que ele é partícipe da atuação. E para dar segurança ao leitor de que não é nenhuma cena irreal o fato de estar amputado, ele faz uso da prolepse: "Levantei a cabeça e vi o que eu continuaria vendo pelo resto da minha vida: que me faltava mesmo a perna direita" (NOLL, 2004, p.77).

Em seguida, aparece o enfermeiro chamado Sebastião. Devido ao total desnudamento físico e dependência em relação ao enfermeiro, se instaura uma boa convivência entre eles. Certo dia, a filha do cirurgião, Diana, visita o ator e domina a cena de forma eloquente, com o entremeio de carícias no corpo dele. Ela fala da candidatura a prefeito de seu pai. Neste momento, Diana o conduz à varanda, onde ele é usado como propaganda do cirurgião Dr.Carlos: "É o artista da novela que o futuro prefeito salvou" (NOLL, 2004, p.83).

Diana o leva à Capela do hospital onde se sugere que os dois viverão um instante erótico. Posteriormente, saberemos que não houve nada, no entanto, o único comentário vindo do ator é este: "Botei a mão na braguilha do pijama, percebi que eu apresentava uma ereção incompleta" (Idem). A omissão do narrador demonstra a ambivalência do corpo grotesco, pois no mundo prosaico a "falha" é motivo de riso. Se ao se erotizar as personagens trazem o mundo incólume para a imperfeição do carnaval, ao se demonstrar que o erótico pode ser patético, temos a alegre relativização apregoada por Bakhtin.

O narrador, depois de ver sua perambulação pelo mundo ser interrompida pela amputação, começa a ver em Sebastião um veículo para continuar em "trânsito". Então ambos arquitetam uma fuga dali. O narrador começa a depositar todas as esperanças em Sebastião, inclusive demonstrando uma grande afeição pelo enfermeiro: "Eu costumava dar atenção plena ao que ele falava - coisa rara em mim, que sempre tivera dificuldade em seguir os outros" (NOLL, 2004, p.87). Com a declaração, legitima toda a atuação praticada até então.

Diana reaparece, querendo ser desvirginada pelo ator na capela, mas pela impossibilidade física ele é abandonado deitado no chão. Cena 
extremamente tocante, que, no entanto, não produz grandes efeitos sentimentais nele. Quem acaba desvirginando a garota é o seu único amigo, Sebastião.

Em alguns dias eles vão fugir.

\section{Sexto ato}

Depois de um longo período de estagnação, em oposição à inquietação latente do narrador, ele volta a transitar, mas agora sob os domínios de Sebastião e seu Wolks. É importante apontar que nesta última parte, Sebastião toma conta completamente das ações, aparentemente algo previsível pelo fato de ele não estar amputado. No entanto, os movimentos de consciência do narrador também diminuíram muito ao se aproximar o final. Sua consciência se ocupa do que a ação externa a obriga. Assim, o ator parece ter aberto mão de atuar para o leitor e muito menos para Sebastião. É como se o ideal do prosaísmo tivesse acontecido: o sujeito se misturou completamente ao outro.

Com o modo de ser estritamente contemplativo, ele assume tal condição ao chegar a Porto Alegre, onde se hospeda com o enfermeiro em um hotel chamado "Hotel Atlântico", devido à proximidade com o mar.

Ao chegar ao quarto, o narrador confidencia algo inusitado, vindo dele: "Tirei o casaco, não que me sentisse acalorado, mas só pelo prazer de jogar o casaco sobre a cama onde eu ia dormir, como se estivesse em casa. E eu realmente me considerava em casa pela primeira vez, depois de tanto tempo" (NOLL, 2004, p.106). É inusitado porque o mal-estar constante que havia nele se dissipou, como se estivesse se fechando um ciclo.

De fato, após tantas carnavalizações e atuações, o herói prosaico deve ser destronado, deve ele também ceder ao tempo. A ambivalência e o movimento grotesco incluem o herói em sua mobilidade, convertendo-o em mais uma demonstração de que a realidade do corpo, vivida pelo herói em sua total completude, foi a atitude mais acertada, considerando que o ciclo em breve se encerraria.

Indícios do fim do ciclo aparecem mais adiante, quando Sebastião conta o que se passou enquanto o narrador dormia: "-Até onde entendi tu dizia que ia voltar pra pegar a camisa azul" (NOLL, 2004, p.108). O "retorno" é, como sabemos, atípico nele, mas desde sua amputação a necessidade de fugir e de se encurralar diminui drasticamente. Outro indício forte é quando ele diz 
ao olhar Sebastião: "Me passou a sensação de que era a última pessoa que eu ia ver" (NOLL, 2004, p.108).

No entrementes, ele tem o mesmo sonho que tivera no ônibus, ao lado de Susan. Nos dois sonhos ele era uma mulher, agora já mutilada. Este sonho não causa estranheza alguma no narrador. $\mathrm{O}$ fato de abrir mão de sua masculinidade momentaneamente não é motivo de nenhum comentário revelando que aquilo the causava perplexidade. Isto se explica quando pensamos em sua identidade que tenta se construir através do mar heterogêneo de identidades que é a sociedade, como atesta Moita Lopes (2002) "A experiência humana não é limitada a um grupo étnico particular, a uma raça, a um gênero, a um modo de expressão da sexualidade (grifo nosso) etc." (p.90). Com tal questão em vista, sua experiência feminina não deixa de ser uma extensão de sua busca por completar-se, encontrar-se; e o "masculino" se mostra, aqui, como algo também inacabado, suscetível a novas possíveis completudes, porque em nenhum patamar da vida ele encontra uma consonância perfeita entre o que ele é e os padrões instituídos de comportamento. $\mathrm{O}$ ator (e suas representações) está ciente do jogo entre ser/parecer e vive mal se equilibrando entre as fissuras e os abismos dos dois polos.

Para a arquitetônica do romance, Noll está chamando a nossa atenção quanto à dramaticidade identitária, quando nenhum de nós encontra um nicho perfeitamente adequado no qual nos encaixarmos com conforto, longe dos maremotos de nossa personalidade fluida e multifacetada, mais que nunca, sujeita às contingências sociais da História.

A última cena do romance é de total regeneração: o narrador cai no quarto já surdo e é levado por Sebastião para a areia do mar, onde, aos poucos, ele perde a visão e morre. Para um sujeito que, ciente de sua incompletude, buscou incessantemente os sentidos (a exacerbação deles), a experiência efêmera do outro, enfim, buscou o impossível, o momento de fusão total com a morte. Fecha seu ciclo vital de buscas infrutíferas.

A imagem da morte como renascimento ou regeneração fica clara nesta frase que ele diz antes de cair no quarto: "O primeiro dia do mundo" (NOLL, 2004, p.109). Sem dúvida, a ambivalência da morte está presente na sentença já que o seu último dia é o primeiro dia do mundo. A morte fecunda, que dá vida. O movimento grotesco que, tal como a imagem da "velha grávida", evocada por Bakhtin (1999), comporta em si a proximidade da morte da velha (o último dia) e a proximidade da vida do bebê (o primeiro dia): 
Entre as célebres figuras de terracota de Kertch (...), destacam-se velhas grávidas cuja velhice e gravidez são grotescamente sublinhadas. Lembremos ainda que, além disso, essas velhas grávidas riem. Trata-se de um tipo grotesco muito característico e expressivo, um grotesco ambivalente: é a morte prenhe, a morte que dá a luz. (p.22).

Voltando à trama, diante de um Hotel se iniciou o romance e diante do Atlântico termina, e o ciclo se encerra. O que se abriu no indeterminado, fecha-se na morte, quem sabe o único ato concluso para quem fez de sua vida constante peregrinação e busca.

\section{Conclusões}

À guisa de conclusão, retomemos o périplo de nosso ator. Em um primeiro momento, ele se encontra em um hotel, sentindo-se acuado, perseguido. Há a ocorrência do assassinato, ele atua com desenvoltura, esquivando-se de responsabilidades.

Depois, ele sai às ruas, se desespera diante da multidão que enfrenta. No ônibus, conhece Susan que morre em seguida. No $3^{\circ}$ ato, ele viaja com os dois desconhecidos, passam pelo prostíbulo e ele acaba tendo que fugir de ambos. Neste ato ele cede a atuação aos dois irmãos. No quarto momento, ele se instala na igreja, onde realiza as cenas mais teatrais do romance, vestido de padre. Na parte final do romance, depois da amputação de sua perna, ele é só contemplação, quem age é Sebastião.

Notamos que sua perambulação e a atuação em si são símbolos do sujeito fragmentado de nossa época, que o esfacelamento das verdades históricas deixou o sujeito à deriva no mar de incertezas, afinal, como diz Silviano Santiago (1995):

O homem está onde nunca esteve (...) leva-o a dialogar com as forças plurais que o cercam e o questionam, conduzindo-o a uma atitude que, longe de negar a sua busca de identidade, procura construí-la sem detrimento das identidades dos outros grupos em nome dos quais egoística e autoritariamente falava. (p.102).

Este sujeito não consegue, e tem ciência disto, estabelecer nenhuma relação, nenhum Encontro. Os vínculos são fugazes, o sujeito de Noll busca, 
com suas máscaras aquilo que é próprio do romance, tendo em vista suas raízes históricas: antigênero por excelência, do ponto em que surgiu: a praça pública, onde os corpos se misturam e se completam.

Tal razão nos leva a considerar que a relação do narrador com o mundo possui os mesmos elementos que constituem uma atuação. No entanto, a atuação não é tão somente um jogo que se estabelece entre ele e o mundo, mas uma condição necessária aos objetivos do narrador e à sua errância. Tal condição é explicitada pelos já citados Clark \& Holquist (2004):

O modo como eu crio a mim mesmo é por meio de uma busca: eu saio de encontro ao outro para voltar com um self. Eu 'vivo na' consciência de um outro; eu vejo o mundo através dos olhos deste outro. Mas não devo jamais fundir-me inteiramente com esta versão das coisas, pois quanto maior for o meu êxito em fazê-lo, tanto mais serei presa das limitações do horizonte do outro. (p.102).

Concluímos, dizendo que romances como os de Noll nos obrigam a pensar sobre a nossa época e, fatalmente, sobre as épocas antecedentes, implicam um movimento em permanente ligação com o passado, mesmo que seja um passado em demolido, pois como diz Hall (2003):

Dentro de nós há identidades contraditórias, empurrando em diferentes direções, de tal modo que nossas identificações estão sendo continuamente deslocadas. Se sentimos que temos uma identidade unificada desde o nascimento até a morte é apenas porque construímos uma cômoda "narrativa do eu. (p.13).

Assim sendo, vamos acompanhando as contradições e tentando entender, olhando para trás, a origem da pulverização da identidade e identificando os símbolos prosaicos evocados pelo romance.

\section{Referências}

BAKHTIN, Mikhail. Questões de literatura e estética: a teoria do romance. 4.ed. Trad: Aurora F. Bernardini, José P. Júnior, Augusto G. Júnior, Helena S.Nazário, Homero F. de Andrade. São Paulo: Editora UNESP, 1998.

. Problemas da poética de Dostoiévski. Trad. Paulo Bezerra. Rio de Janeiro: Forense Universitária, 1997. 
. A cultura popular na Idade Média e no Renascimento: o contexto de François Rabelais. 4.ed. Trad: Iara Frateschi. São Paulo-Brasília: Edunb/HUCITEC, 1999.

CAMUS, Albert. O mito de Sísifo. Tradução de Ari Roitman e Paulina Watch. Rio de Janeiro: Record, 2005.

CLARK, K. \& HOLQUIST, M. Mikhail Bakhtin. Trad. J. Guinsburg. São Paulo: Perspectiva, 2004.

ECO, Umberto. Seis passeios pelos bosques da ficção. Trad. Hildegard Feist. São Paulo: Cia. Das Letras, 1994.

HALL, Stuart. A identidade cultural na pós-modernidade. 8.ed. Rio de Janeiro: DP\&A, 2003.

MOITA LOPES, Luiz Paulo da. Identidades fragmentadas: a construção discursiva de raça, gênero e sexualidade em sala de aula. Campinas: Mercado de Letras, 2002. v. 1.

NOLL, João Gilberto. Hotel Atlântico. São Paulo: Francis, 2004.

. Harmada. São Paulo: Companhia das Letras, 1993.

PELLANDA, Luis Henrique (Org.). As melhores entrevistas do Rascunho. Porto Alegre: Arquipélago Editorial, 2010. v.1.

SANTIAGO, Silviano. Arte masculina? In: NOLASCO, Sócrates (Org.). A desconstrução do masculino. Rio de Janeiro, Rocco, 1995.

Recebido para publicação em 08 nov. 2010.

Aceito para publicação em 20 dez. 2010. 